\title{
Description of immature stages of Xestia brunneopicta (Matsumura, 1925), with a key to the mature larvae of the European species of Xestia (Pachnobia) (Lepidoptera, Noctuidae)
}

\author{
Matti Ahola ${ }^{1}$, Martti Kuisma ${ }^{2}$, Reima Leinonen ${ }^{3}$, Hannu SaArenmaA $^{4}$, \\ Kimmo SiLvONEN ${ }^{5}$ \\ 1 Metsänreunantie 27 G, FIN-85900 Reisjärvi, Finland; mj.ahola@kotinet.com \\ 2 Annalantie 107,FIN-14610Lepaa, Finland; martti.kuisma@pp3.inet.fi \\ 3 Rauhalantie 14 D 12,FIN-87830Nakertaja, Finland; reima.leinonen@kajaani.net \\ 4 University of Eastern Finland, SIB Labs Digitarium, P.O. Box 111, FIN-80101 Joensuu; hannu.saarenmaa@uef.fi \\ 5 Pronssitie 28,FIN-02750Espoo; silvonen@kolumbus.fi
}

http://zoobank.org/53BD7012-FBB9-4708-BC97-88C4B35BFD44

Received 29 January 2015; accepted 16 March 2015; published: 12 May 2015

Subject Editor: Alberto Zilli.

\begin{abstract}
Immature stages of Xestia brunneopicta (Matsumura, 1925) are described and illustrated from an ex ovo rearing. The female was collected during a Finnish-Russian expedition to the province of Chita in East Siberia in 2013. Eggs were laid in a plastic jar at Chara Sands on the $7^{\text {th }}$ of July. Larvae hatched between the $20^{\text {th }}$ and $21^{\text {st }}$ of July. Rearing of larvae was undertaken in Finland by four lepidopterologists. A key is given that includes the known European larvae of the subgenus Pachnobia Guenée, 1852 sensu Lafontaine et al. (1998), mostly based on the morphology and larval chaetotaxy. The closest relatives on the basis of larval morphology are discussed.
\end{abstract}

\section{Introduction}

The early stages of Xestia brunneopicta (Matsumura, 1925) have remained undescribed in spite of its wide distribution from Magadan to the East-Siberian Tuva in Russia (Kononenko 2005) and rarely also in Kuusamo, Finland (Mikkola et al. 1989). Ahola and Silvonen (2011) described larvae found in nature in 1982 (Kuusamo) and 1992 (Kuusamo, Kuhmo) as X. brunneopicta on the basis of their differences in chaetotaxy and habitus compared to those of $X$. gelida (Sparre-Schneider, 1883). However, through the recent findings, we can now state that the larvae of $X$. gelida and the real $X$. brunneopicta are very distinct from each other, particularly in their outer appearance, as shown in this paper. The Finnish larvae formerly reported as Xestia brunneopicta are now re-identified as those of $X$. gelida even though some of their characters differ slightly from other individuals of $X$. gelida examined. Egg, larva and pupa of $X$. brunneopicta are described and illustrated.

Pachnobia was described by Guenée, 1852 as a genus and based on the type-species Pachnobia carnea, a misidentification of Noctua tecta (Hübner, 1808) (Poole 1989). In Poole's catalogue (1989) Pachnobia was included as a synonym in the large genus Xestia Hübner, 1818. Lafontaine (1998) arranged Xestia into four subgenera: Xestia, Megasema Hübner, 1821, Pach- 
nobia and Raddea Alpheraky, 1892. Two subgenera, Anomogyna Staudinger, 1871 and Schoyenia Aurivillius, 1883, were included in Pachnobia, because of larval characters. We follow here this opinion, although some other concepts have been published later (for instance Beck 1999, Fibiger and Hacker 2005, Ahola and Silvonen 2011). A key to the larvae of 18 European species of Xestia (Pachnobia) is provided and it is mainly based on their morphology and chaetotaxy.

\section{Materials and methods}

The larval material originates from a female collected during an expedition to the province of Chita in East Siberia, N56.87133, E118.18302, at an elevation of 750 m.a.s.l. on 7.vii.2013 by Hannu Saarenmaa. Seventy-two eggs were laid on the needles of Larix gmelini Rupr. (Pinaceae) in a plastic jar at Chara Sands $7-10$ July. The rearing of eggs was carried out in Finland by HS and 60 larvae hatched after two weeks on 20-21 July. All larvae were reared under different lamps from 18 to 24 hours of light every day, because the northern larvae grow faster in continuous daylight. Twenty larvae grew to maturity during autumn and went into diapause instead of pupating. We follow Beck (2000) in descriptions of cuticular ornaments. Two larvae were prepared by dry inflating. Larval chaetotaxy nomenclature follows Hinton (1946) while pupal follows Patočka and Turčáni (2005). The hypopharyngeal complex, mandibles and labrum were dissected and preserved on a slide to study the morphology.

\section{Descriptions of immature stages}

Egg (Fig. 6): The eggs were laid on the needles of Larix gmelini. Shortly after laying they were whitish grey, but fertile eggs darkened in two days. The micropyle area became dark reddish brown, and the narrow zone around the micropyle was reddish brown

Morphology of full-grown larva (Figs 1-5): Spinneret flat, $2.5 \times$ as long as wide, ventral lip straight, dorsal lip short-fringed, longitudinal grooves present on dorsal surface. Base segment of labial palp (Lps1) about $2 \times$ as long as wide, second segment (Lps2) 1/5 as long as Lps1, labial palp seta Lp1 slightly longer than Lps2, seta Lp2 shorter than Lps1 (3/5) and 2× as long as Lp1. Hypopharynx with long spines on anterior surface above spinneret, distolateral spines slightly longer and stouter than distomedian spines, spines on lateroposterior part forming row of 8-10 differentiated, triangular teeth, lateral surface above this row densely covered with tiny spinules, posterior area of medial part bare. Stipular setae below spinneret shorter than seta Lp2 of labial palp, situated in front of prementum. Mandible with two setae on outer surface, six teeth on cutting margin, three ridges on inner surface terminating in low protuberances before cutting margin and triangular tooth on first ridge. Maxillary palp three-segmented, second segment longer than galeal lobe, sensillum styloconicum of galeal lobe as long as end segment of maxillary palp, three sensilla trichodea present. Labrum with low, rounded notch. Epicranial suture slightly shorter than height of frons. Six stemmata present, distance between second (Oc2) and third (Oc3) stemma greater than those between Oc1-Oc2 or Oc3-Oc4, distance Oc1-Oc2 greater than Oc3-Oc4. Abdominal prolegs on abdominal segments 3- 6 (Ab3-6) equal in size, crochets uniordinal, 17-20 on Ab3, 22-24 on Ab6 and 26-28 in Ab10. Body without warts or other protuberances.

Chaetotaxy resembling that of other members of Pachnobia: Setae of head and body rather long when compared to the height of the spiracle on Ab8: P1 on head 3.1-3.3×, D2 on Ab2 


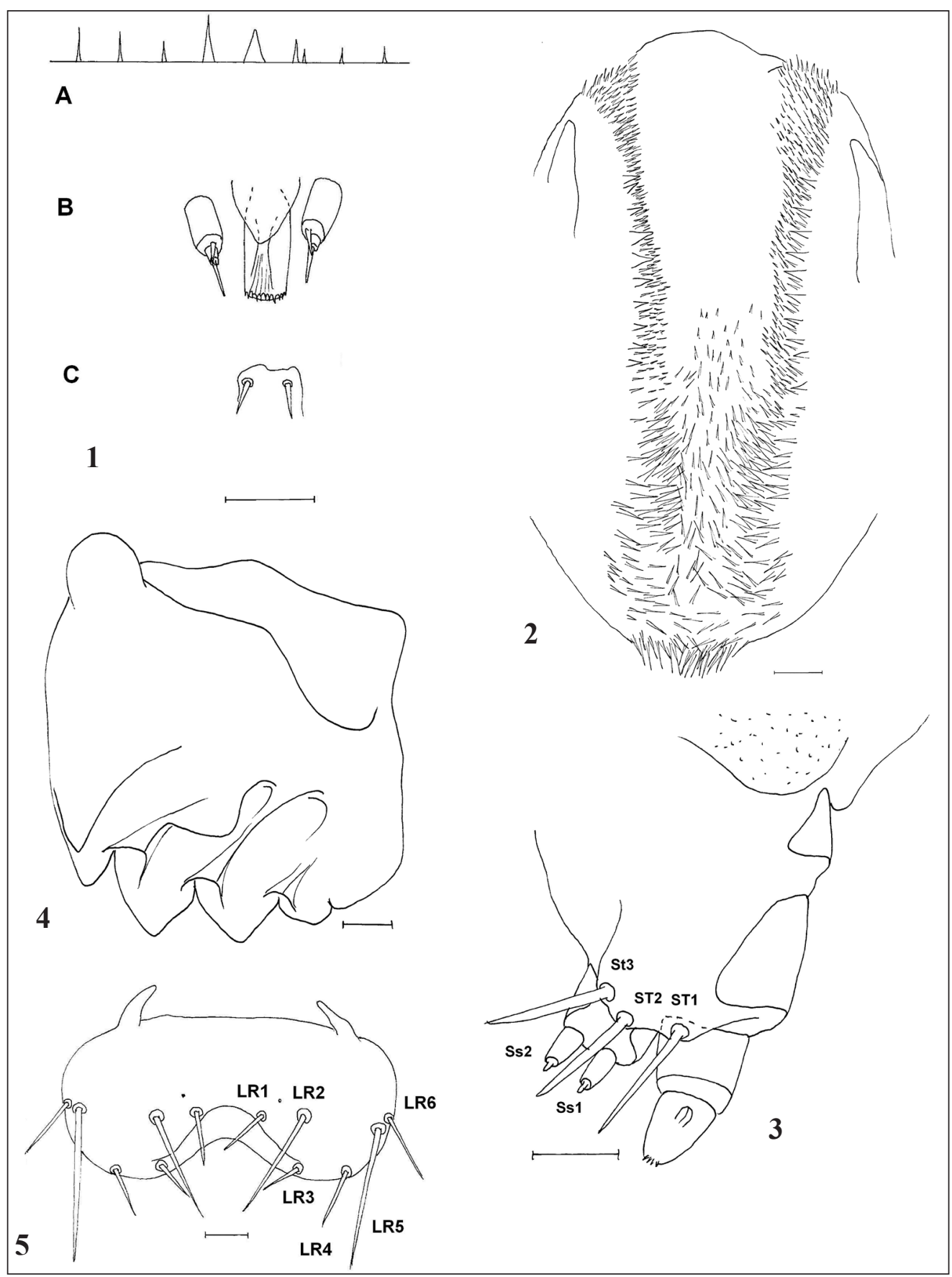

Figures 1-5. X. brunneopicta, morphology of larval mouth parts. 1. A. Scheme of spines of hypopharynx, from left: distoanterior, distomedial, distoposterior, distolateral, lateral tooth, posterior dorsolateral, posterior medial and lateroposterior spines. B. Spinneret and labial palpi in dorsal view. C. Stipular setae in frontal view. 2. Hypopharynx in dorsal view. 3. Left maxilla in dorsal view. 4. Left mandible in oral face. 5. Labrum in dorsal view. Scale $0.1 \mathrm{~mm}$. 
Table 1. Relevant distances between setae of larva of Xestia brunneopicta $. \mathrm{Ab}=$ abdominal segment.

\begin{tabular}{c|c|c|c|c}
\hline Segment & Ratio of distances & Range & Mean & N \\
\hline Head: & AF1-AF2/AF1-F1 & $1.5-1.6$ & 1.55 & 2 \\
\hline & P1-A2/A1-A2 & $3.3-3.7$ & 3.5 & 2 \\
\hline & SO1-SO2/SO2-SO3 & $2.0-2.7$ & 2.4 & 2 \\
\hline Metathorax: & SD2-L1/SD1-SD2 & $0.7-1.0$ & 0.8 & 2 \\
\hline Abdomen: & & & & \\
\hline $\mathrm{Ab} 2$ & SD1-SD2/SD2-spiracle 2 & $1.4-1.5$ & 1.45 & 2 \\
\hline & SV1-SV3/SV1-SV2 & $0.8-0.9$ & 0.86 & 2 \\
\hline $\mathrm{Ab} 7$ & SD1-SD2/SD2-spiracle 7 & $1.8-2.2$ & 2.0 & 2 \\
\hline & L2-L3/L3-SV1 & $0.7-0.9$ & 0.8 & 2 \\
\hline $\mathrm{Ab} 9$ & D2-SD1/D1-SD1 & $0.6-0.8$ & 0.7 & 2 \\
\hline $\mathrm{Ab} 10$ & D2-SD1/D2-D2 & $2.2-2.9$ & 2.6 & 2 \\
\hline & D1-D1/D2-D2 & $2.6-3.8$ & 3.2 & 2 \\
\hline
\end{tabular}

1.6-1.9×, D2 on Ab7 1.3-1.5× and D2 on Ab8 2.1-2.2× height of spiracle 8. Seta SD1 hair-like on thorax and $\mathrm{Ab} 9$, tonofibrillary platelet present below seta SD1 on meso- and metathorax and two SV setae on Ab1. Relevant larval setal distances are presented in Table 1.

First instar larva: Length about $2 \mathrm{~mm}$. Head pale brown, body pale greenish grey with small dark- brown setal bases. Prolegs on Ab3-6 well developed, those on Ab3-4 much smaller (Fig. 7).

Second instar larva: Length about $4 \mathrm{~mm}$. Head brown. Dorsal region greenish, ventral region pale yellowish green, setal bases dark brown. Narrow, whitish dorsal and subdorsal lines present, shields on thoracic segments 1 (Th1) and Ab10 pale brown (Fig. 8).

Third instar larva: Length about 7-9 mm. Head brown, stripes visible but weak. Shields pale brown, dorsal lines yellowish, not sharp-edged on shields. Dorsal zone green with white, narrow, middorsal and subdorsal lines without darker margins, setal bases small, pale green. Subdorsal zone dark olive green, spiracular line yellowish white, broad. Pleural and ventral zones pale green (Fig. 9).

Fourth instar larva (Fig. 10): Length 14-18 mm: Head brown, netfields visible but translucent, frons and anterior zone green, brown setal points on brown bases. Thoracic and anal shields pale brown, dorsal and subdorsal lines present as yellowish white flecks on prothoracic shield but absent on anal shield. Body green on dorsal region with pale green or with whitish elements, yellowish green between abdominal segments, dark green on ventral subdorsal zone. Middorsal line nearly white, broad, continuous, subdorsal line slightly narrower, broken into spots. Spiracular line broad, yellowish white, sharply bordered above dark green ventral subdorsal zone. Ventral region pale green. Setal points black on dorsal region with dark green dorsal/whitish ventral bases.

Penultimate and last instar (Figs 11-12): Length of last instar larva 35-40 mm. Head brown, stripes brown, reticulate structure with brown bands and pale brown, weakly visible netfields. Frons and anterior zone greenish, adfrons brown, ocellar zone pale yellowish brown, setal points dark brown. Prothoracic shield darker green than body, with narrow pale grey middorsal line, subdorsal line not visible, shield caudally bordered with narrow, blackish grey colour. Anal shield greenish brown, lines not visible, sutures brown, setal points blackish brown. Dorsal and ventral regions of body green, middorsal and subdorsal 


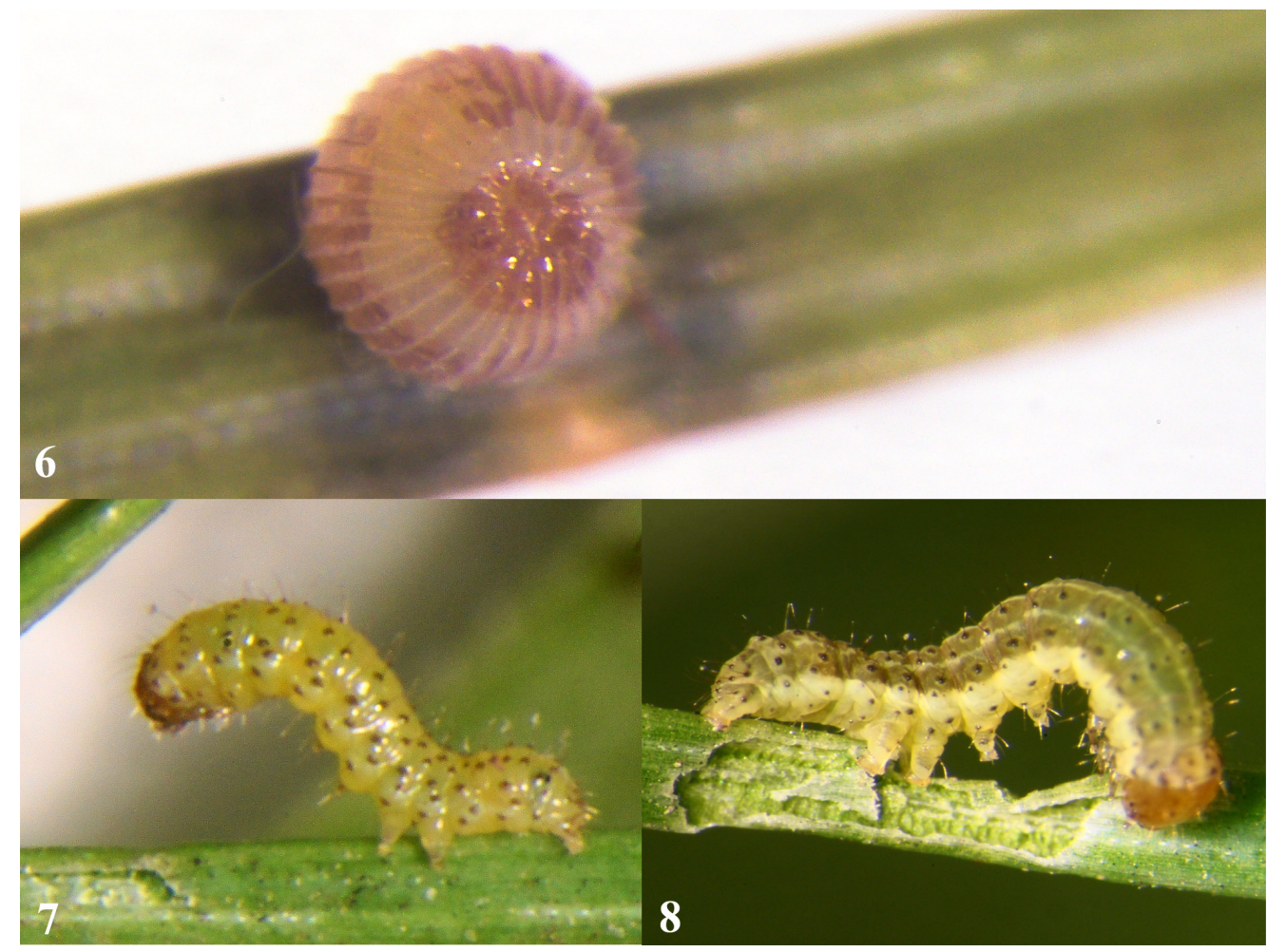

Figures 6-8. Egg and small larvae of X. brunneopicta. 6. Egg on needle of Larix gmelini (Photo: M. Ahola). 7. The $1^{\text {st }}$ instar larva on needle of Larix sibirica (Photo: M. Ahola). 8. The $2^{\text {nd }}$ instar larva on needle of Larix sibirica (Photo: M. Ahola).

lines white, narrow, short and broken, not visible on Ab9-10, both lines with dark-green margins. Dorsal part of spiracular line visible, white, narrow, dorsally dark violet-green border, ventrally no border. Dorsal and subdorsal zones mottled by small, white elements and longitudinal violet-green colour elements; dorsal zone with diffuse wedge-shaped diamond figures; setal points of D1 and D2 black with small white bases, microsetae MD1 and MD2 on common large and white base on metathorax, other MD1 bases also white but small. Spiracles yellowish with black edges. Thoracic legs with green coxae and pale brown tibiae, prolegs green.

Pupa (Figs 13-14): Dark brown. Frons without tubercles or projections, labium and labial palpi visible, proboscis exceeding caudal margin of $\mathrm{Ab} 4$, prothoracic femora visible, thoracic legs adjacent to antennae. Abdominal spiracles narrow, Ab5-7 without elevated transverse ridge in front of spiracles, without transverse row of spines or lateral spines; punctuation present close to bases of Ab4-7. Cremaster short, flat, quadrangular, with transverse dorsal and ventral furrows and three pairs of setae, D2 close together, short and hook-like, D1 longer than D2, stout, L1 short and stout, situated beside D2 on caudal margin of cremaster. Pupation after hibernation without feeding in flimsy weak cocoon. 


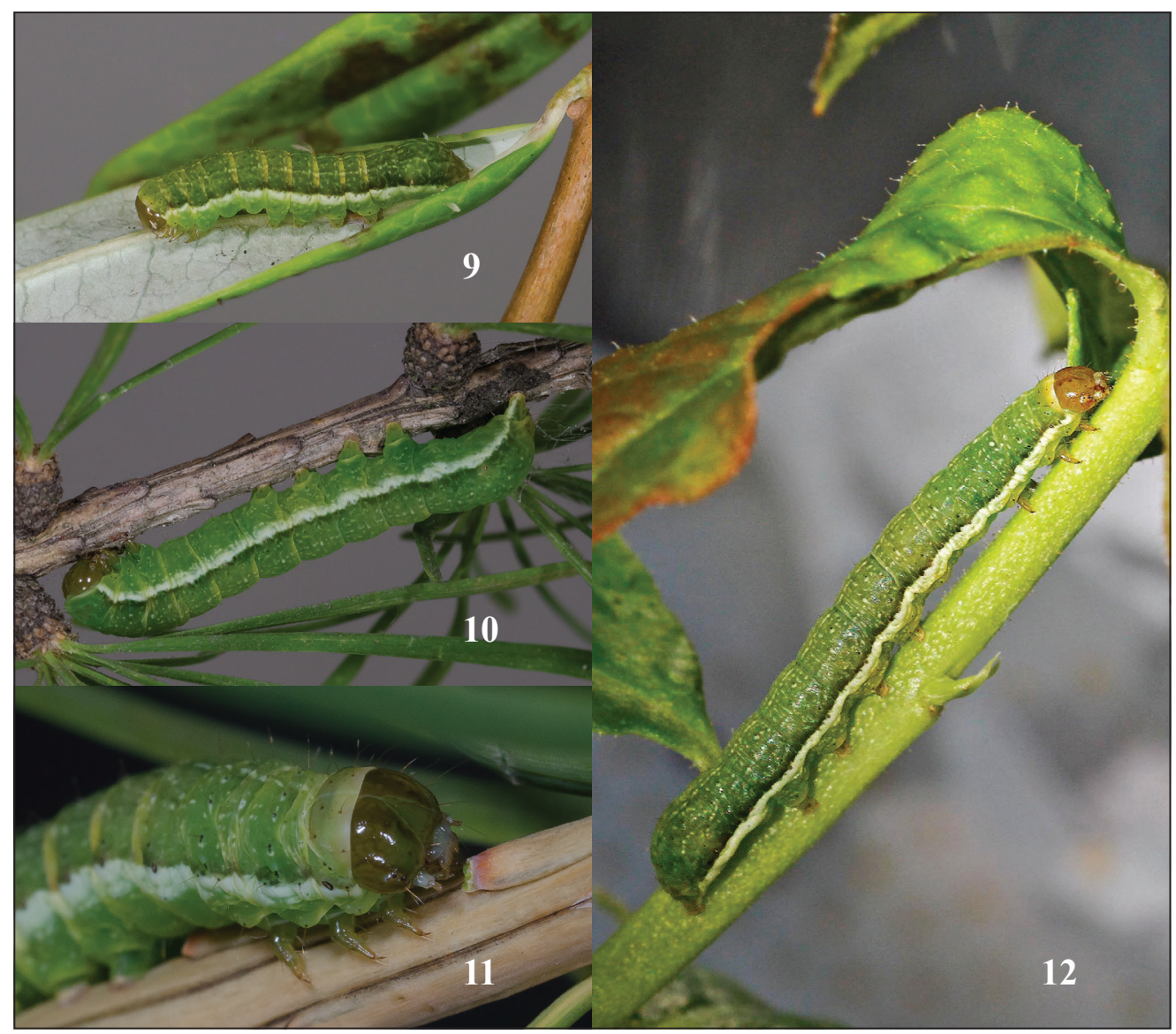

Figures 9-12. X. brunneopicta larvae. 9. The $3^{\text {rd }}$ instar larva on Andromeda polifolia L. (Photo: K. Silvonen). 10. The $4^{\text {th }}$ instar larva on Larix decidua Miller (Pinaceae) (Photo: K. Silvonen). 11. Last instar larva with darker brown head (Photo K. Silvonen). 12. Mature larva on Salix phylicifolia. (Photo: P. Puntila).

\section{Observations on rearing and host plants}

Larvae hatched on July 20 and 21. They were in a plastic jar where they could choose between plants Larix sibirica Maxim. (Pinaceae), Vaccinium myrtillus L. (Ericaceae) and Polygonum aviculare L. (Polygonaceae). About 40 of the 60 larvae chose L. sibirica or V. myrtillus and the rest chose $P$. aviculare. Five larvae died during the first week for unknown reasons. After about a week the group of larvae was divided amongst four Finnish lepidopterists. It appeared later that young larvae could feed also on Poa annua L. (Poaceae) and Salix phylicifolia L. (Salicaceae). Full-grown larvae were rather polyphagous in laboratory conditions, feeding also on Rubus idaeus L. (Rosaceae), Alnus incana (L.) Moench (Betulaceae), Salix sp. (Salicaceae) and Lonicera xylosteum L. (Caprifoliaceae). Larvae were mostly reared under a lamp.

\section{Notes on natural environments}

The collecting site of the female in Chara Sands is a peculiar dune habitat with occasional springs, bogs and coniferous tree patches. It does not represent the typical habitat of the species. 


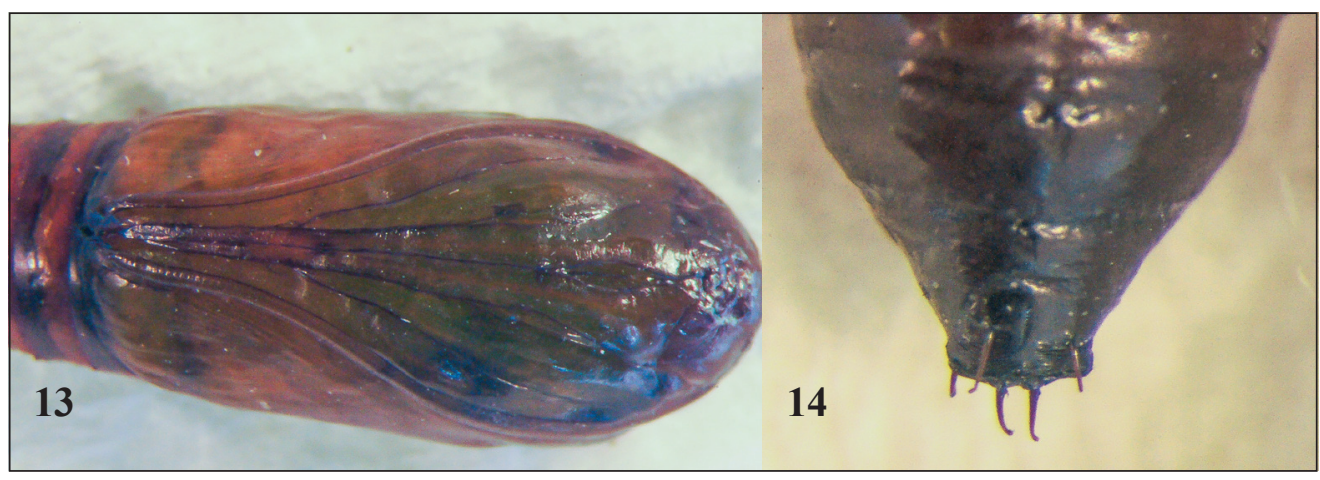

Figures 13-14. X. brunneopicta pupae. 13. Pupa in ventral view. 14. Cremaster of pupa in dorsal view (Photos: M. Ahola).

During the trip (3-12 July) other localities near Chara were investigated, for which another article on the results of the expedition is under preparation (Saarenmaa et al., in prep.). $X$. brunneopicta was common across all sites, but it seemed to be more frequent in the lowlands than in the mountain valleys. Typical habitat for the species is forested bog with Larix gmelini (Fig. 15). However, it was most numerous in low Salix and Alnus vegetation on the banks of the Chara River. Other species typical for these localities include several other Xestia (Pachnobia) species such as X. atrata (Morrison, 1874), and also Polia altaica (Lederer, 1853), P. conspicua (A. Bang-Haas, 1912), P. vespertilio (Draudt, 1934), P. vesperugo Eversmann, 1856, and the arctiine Borearctia menetriesii Eversmann, 1846.

\section{Key to the larvae of subgenus Pachnobia}

Larvae of the subgenus Pachnobia differ from subgenera Megasema and Xestia in chaetotaxy and morphology. Dorsal setae are long in Pachnobia, seta D2 on Ab8 is more than twice as long as height of spiracle of same segment, whereas it is about as long as height of spiracle in subgenera Megasema and Xestia. Also, setal distances P1-P2 (head) and V1-V1 (Ab7) differ on average (Table 2). Spinneret of larvae in subgenus Pachnobia is long, about 1.5-5.0× as long as wide, flat (except $X$. liquidaria), dorsal margin with short fringes (without fringes in $X$. liquidar$i a$ ) and ventral margin straight. Megasema and Xestia larvae have a short spinneret, 1.0-1.5× as long as wide (except $2-3 \times$ in $X$. collina, castanea and agathina), dorsal margin with longer fringes and ventral margin more or less bilobed. Body colour and pattern vary a lot. Larva of $X$. liquidaria is peculiar with a tubular spinneret but long dorsal setae as in subgenus Pachnobia.

Larvae of European species of Xestia (Pachnobia) albonigra (Kononenko, 1981) and X. (Pachnobia) thula Lafontaine \& Kononenko, 1983 are still unknown, and are not included in the following key.

1 Netstructure of head negative, netfields darker than bands, spinneret tubular, distal part of hypopharynx bare, without spines or granules, subdorsal line wide, white, spiracular line absent. Ratio of setal distance L1-L3/L1-L2 on Th3 varies 0.9-1.0, mean 1.1, $\mathrm{N}=2$ and on Ab2 ratio of setal distances SD1-SD2/SD2-ST2 varies 4.55.3, mean $4.9, \mathrm{~N}=2$ Xestia (Pachnobia) liquidaria (Eversmann, 1848) 


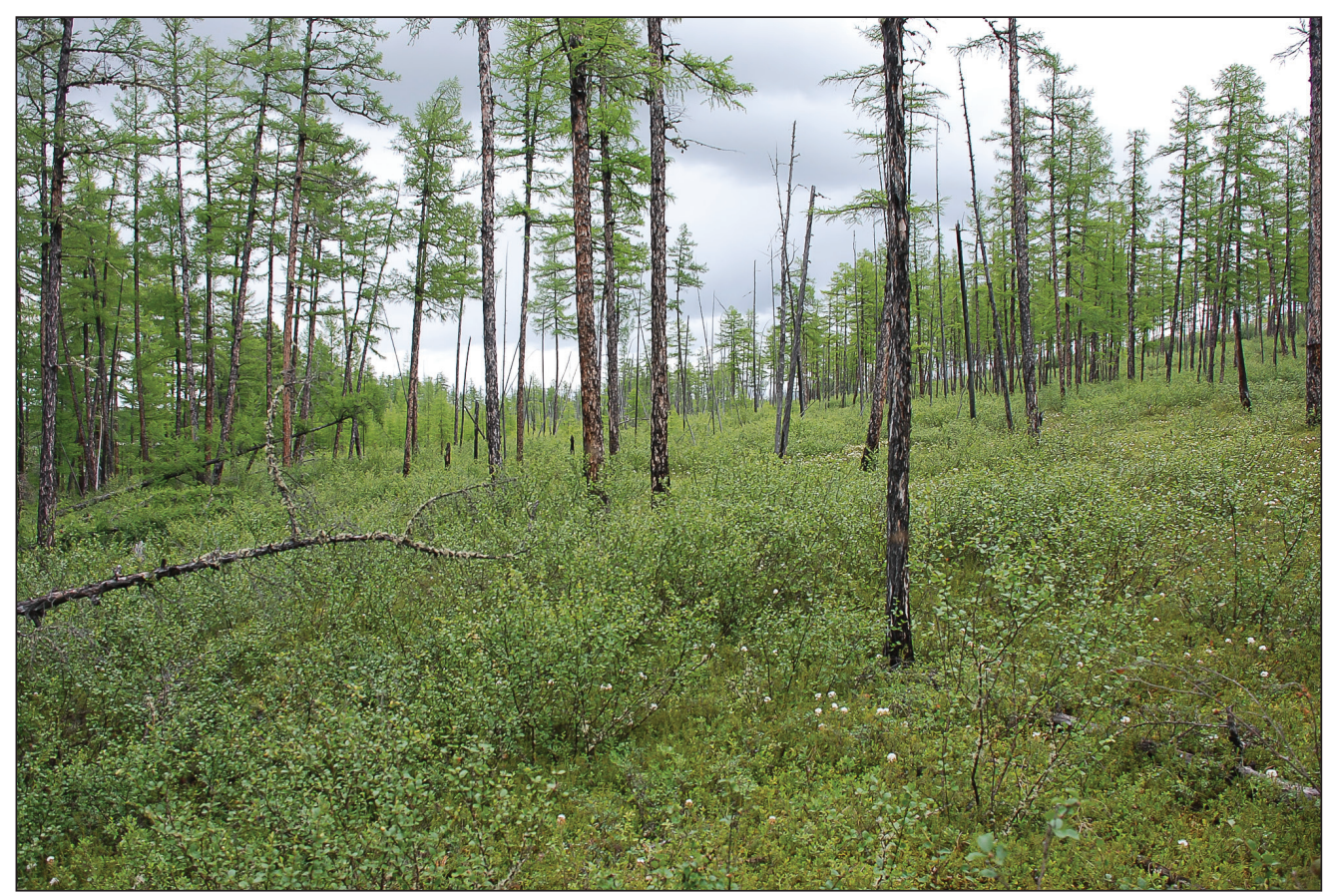

Figure 15. Typical habitat of X. brunneopicta and the other species mentioned in the article. Chara River with richer vegetation on its banks is 100 meters to the left (Photo: H. Saarenmaa).

Table 2. Differences in chaetotaxy between larvae of Pachnobia and Megasema + Xestia $. \mathrm{Ab}=$ abdominal segment, ST = spiracle.

\begin{tabular}{c|c|c|c|c|c|c}
\hline Ratio between setal distances: & Pachnobia range & Mean & $\mathbf{N}$ & Megasema and range & Xestia mean & N \\
\hline Head: P1-P1/P1-P2 & $1.4-2.9$ & 2.1 & 152 & $2.0-4.1$ & 3.0 & 66 \\
\hline Ab7: V1-V1/SV1-V1 & $0.4-1.7$ & 0.8 & 153 & $0.3-1.1$ & 0.5 & 66 \\
\hline Length of seta & & & & & & \\
\hline D2Ab8/height of ST8 & $1.4-5.4$ & 2.6 & 139 & $0.7-1.6$ & 1.0 & 66 \\
\hline
\end{tabular}

- $\quad$ Netstructure of head positive, netfields paler than bands, spinneret flat, distal part of hypopharynx covered with spines or granulated, lines of body vary. Ratio of setal distance L1-L3/L1-L2 on Th3 varies 1.2-3.3, mean 1.8, $\mathrm{N}=146$ and ratio of setal distances SD1-SD2/SD2-ST2 on Ab2 varies 1.1-4.3, mean 2.2, $\mathrm{N}=137$ .2

2 Mandible without inner teeth or sometimes low swelling present on first ridge, transverse cleft of hypopharynx not visible, setae very long, length of seta D2 on Ab8 more than $3 \times$ height of spiracle on same segment (mean 3.4, range $2.2-5.0, \mathrm{~N}=27$ ),

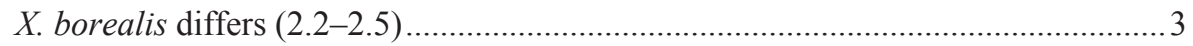

- $\quad$ Mandible with 1-2 triangular teeth, hypopharyngeal transverse cleft usually present, setae shorter, length of seta D2 on Ab8 about $2 \times$ height of spiracle on same segment (mean 2.3, range 1.4-4.2, $\mathrm{N}=109)$, X. sincera differs (3.5-4.2)............................ 9

3 Mandible with low swelling on first ridge, location of pore XDc close to seta XD2 on prothoracic shield (ratio XD1-XDc/XD2-XDc ranges 2.1-6.0, mean 3.3, $\mathrm{N}=7$ ), on 
anal shield setal distance D1-SD2 longer than D1-D2 (ratio D1-SD2/D1-D2 ranges 1.1-1.5, mean 1.3, $\mathrm{N}=7$ ). Head small, thorax tapered towards head, setal bases D1 and D2 as white, sharp-edged full-bases. Mandible without swelling on first ridge, location of pore XDc more distant from seta $\mathrm{XD} 2$ on prothoracic shield (ratio XD1-XDc/XD2-XDc ranges 1.4-3.0, mean 2.1, N $=20$ ), on anal shield setal distance D1-SD2 mostly shorter than D1-D2 (ratio D1SD2/D1-D2 ranges 0.8-1.3, mean 0.9, $\mathrm{N}=18$ ). Thorax not tapering towards head, setal bases D1 and D2 yellowish, greyish or absent and not sharp edged................. 5 Dorsal zone pale violet whitish with darker arrow-chevron figure, subdorsal zone blackish, subdorsal line yellowish white ventrally bordered by black diagonal bands, spiracular line pale brownish beige, paler than greyish-brown pleural zone.

Xestia (Pachnobia) fennica (Brandt, 1936)

Dorsal zone uniformly red-brown without arrow-chevron figure, subdorsal zone dark red-brown dorsally, subdorsal line whitish broken to few flecks, spiracular line reddish beige like pleural zone. Xestia (Pachnobia) rhaetica (Staudinger, 1871) Hypopharynx with row of long posterior lateral spines, about as long as distal lateral spines, distance between ocelli Oc1-Oc2 shorter than that of Oc2-Oc3 (ratio Oc1Oc2/Oc2-Oc3 ranges $0.6-0.8$, mean $0.7, \mathrm{~N}=7$ ), seta $\mathrm{P} 1$ on head shorter than $1.5 \times$ seta $\mathrm{D} 2$ on $\mathrm{Ab} 2$ (ratio $\mathrm{P} 1 / \mathrm{D} 2$ range 1.2-1.5, mean 1.4, $\mathrm{N}=7$ ), on anal shield distance D1-D1 more than $3 \times$ that of D2-D2 (ratio D1-D1/D2-D2 range 2.9-4.1, mean 3.4, N $=7$ ). Frons and stripes black or blackish brown on head, coxae of thoracic legs black, subdorsal lines yellowish on prothoracic and anal shields ... 6 Hypopharynx with row of shorter posterior lateral spines, shorter than distal lateral spines, or without differentiated spines in this area, distance between ocelli Oc1Oc2 about as long as that of Oc2-Oc3 (ratio Oc1-Oc2/Oc2-Oc3 ranges 0.8-1.7, mean $1.1, \mathrm{~N}=13$ ), seta $\mathrm{P} 1$ on head longer than $1.5 \times$ seta $\mathrm{D} 2$ on $\mathrm{Ab} 2$ (ratio P1/D2 range 1.5-2.0, mean 1.7, $\mathrm{N}=7$ ), on anal shield distance D1-D1 about 2x that of D2-D2 (ratio D1-D1/D2-D2 range 1.2-2.9, mean 2.1, N = 12). Head with brownish or grayish frons and stripes, coxae of thoracic legs paler, subdorsal lines whitish or grayish on shields Spinneret about $1.5 \times$ as long as wide. Dorsal zone of larva darker reddish grey, black, wedge-shaped flecks above subdorsal line wide, coming into contact with both D1 and D2 bases on Ab8, this line sharp also on shields, pinacula at bases of D setae visible only on Ab9 Xestia (Pachnobia) laetabilis (Zetterstedt, 1839)

- $\quad$ Spinneret about $2 \times$ as long as wide. Dorsal zone of larva pale grey with reddish tinge, black wedge-shaped flecks above subdorsal line narrow, coming into contact only with D2 bases, this line obscure, broken into spots on shields, pinacula at bases of D setae present on Ab1-9 Xestia (Pachnobia) distensa (Eversmann, 1851) Differentiated posterior lateral spines absent on hypopharynx, seta Lp1 of labial palpus unusually long, about $4 \times$ length of second segment of labial palpus, seta $\mathrm{P} 1$ on head shorter than epicranial suture (ratio P1/Es range $0.8-0.9$, mean $0.8, \mathrm{~N}$ $=3$ ), setal distance SD1-SD2 about $2 \times$ as long as distance between seta SD2 and spiracle on Ab2 (ratio SD1-SD2/SD2-spiracle ranges 1.8-2.1, mean 2.0, N = 3). Subdorsal zone lichen patterned with blackish grey and whitish elements, spiracu- 
lar line yellowish white, broad, widely broken below spiracles by ground color and blackish stripe Xestia (Pachnobia) borealis (Nordström, 1933)

Differentiated posterior lateral spines may be weak but present on hypopharynx, seta Lp1 of labial palpus shorter, at most $2 \times$ length of second segment of labial palpus, seta P1 on head longer than epicranial suture (ratio P1/Es range 1.1-2.0, mean 1.5, $\mathrm{N}=10$ ), setal distance SD1-SD2 about $3 \times$ distance between seta SD2 and spiracle on Ab2 (ratio SD1-SD2/SD2-spiracle ranges 2.3-3.7, mean 2.8, $\mathrm{N}=10$ ). Subdorsal zone not lichen patterned, spiracular line obscure or absent . .8 Labial palpus with seta Lp2 as long as first segment, setal bases without pinacula on abdomen, number of crochets on Ab6 29-33, distance between setae D2-D2 short on anal shield (ratio D1-D1/D2-D2 ranges 1.9-2.9, mean 2.5, $\mathrm{N}=5$ ). Larva with prominent, white middorsal and subdorsal lines on dorsal region, subdorsal line bordered by black wedge-shaped dorsal flecks Xestia (Pachnobia) lyngei (Rebel, 1923) Labial palpus with seta Lp2 shorter than first segment, setal bases with pinacula on abdomen, number of crochets on Ab6 18-20, distance between setae D2-D2 long on anal shield (ratio D1-D1/D2-D2 ranges 1.2-1.7, mean 1.5, $\mathrm{N}=5$ ). White dorsal lines narrow, not prominent, and black wedge-shaped flecks absent on dark brown dorsal region Xestia (Pachnobia) quieta (Hübner, 1813) Skin of distal region of hypopharynx granulated with a few spines or bare, mandible with two inner teeth, setal distance D2-SD2 $2 \times$ as long as XD2-SD2 on prothorax (range 1.7-2.8, mean 2.1, $\mathrm{N}=15$ ), length of seta D2 on Ab8 shorter than $2 \times$ as long as height of spiracle (length D2 Ab8/height of spiracle ST8 varies 1.4-2.0, mean 1.7, $\mathrm{N}=15$ ). Frontal stripe of head pale greyish brown, much paler than cervical stripe, and spiracular line of abdomen absent or obscure 10 Skin of distal region of hypopharynx smooth and densely covered with spines, mandible with 1-2 teeth, setal distance D2-SD2 slightly longer than XD2-SD2 on prothorax (range 1.0-2.7, mean 1.4, $\mathrm{N}=119$ ), length of seta D2 on Ab8 longer than $2 \times$ as long as height of spiracle (length D2 Ab8/height of spiracle ST8 varies 1.7-5.0, mean 2.6, $\mathrm{N}=121$ ). Frontal stripe of head mostly of same colour as cervical stripe, and spiracular line usually visible 11

10 Distance between setae D2-D2 on anal shield longer than height of spiracle of Ab8 (ratio D2-D2/height of spiracle ranges 1.0-1.3, mean 1.1, $\mathrm{N}=6$ ), setal distance D1D1 on anal shield about $2 \times$ as long as D2-D2 (ratio D1-D1/D2-D2 ranges 1.7-2.3, mean 2.0, $\mathrm{N}=6$ ). Larva dark reddish brown, middorsal line weak, whitish, mostly covered by blackish brown margins . Xestia (Pachnobia) alpicola (Zetterstedt, 1839) Distance between setae D2-D2 on anal shield shorter than height of spiracle of Ab8 (ratio D2-D2/height of spiracle ranges $0.7-0.8$, mean $0.8, \mathrm{~N}=3$ ), setal distance D1D1 on anal shield about $3 \times$ as long as D2-D2 (ratio D1-D1/D2-D2 ranges 2.7-3.0, mean 2.9, $\mathrm{N}=3$ ). Larva yellowish brown, middorsal line whitish, more visible because of narrower margins ............ Xestia (Pachnobia) albuncula (Eversmann, 1851)

11 Mandible with two inner teeth, setal distance SD1-SD2 mainly less than $2 \times$ that of $\mathrm{SD} 1-$ spiracle on $\mathrm{Ab} 2$ (ratio SD1-SD2/SD1-spiracle varies 1.1-3.3, mean 1.8, $\mathrm{N}=$ 48), X. atrata with longer SD1-SD2 (range 2.1-3.3, $\mathrm{N}=5$ ). Larva brown, subdorsal line not touching bases of setae D2 12 
Mandible with one triangular inner tooth, setal distance SD1-SD2 mainly more than $2 \times$ that of SD1-spiracle on Ab2 (ratio SD1-SD2/SD1-spiracle varies 1.44.3, mean 2.3, N=44), X. gelida and $X$. brunneopicta with short SD1-SD2 (1.4$2.4, \mathrm{~N}=16$ ). Ground colour varies, subdorsal line usually touching bases of D2 setae

nner tooth on first ridge of mandible quadrangular, distance between ocelli Oc1-Oc2 on head longer than that of Oc2-Oc3 (ratio Oc1-Oc2/Oc2-Oc3 ranges 1.0-1.4, mean $1.2, \mathrm{~N}=5$ ), seta $\mathrm{D} 2$ closer to spiracle on Ab2 (ratio SD1-SD2/SD2-spiracle ranges 2.1-3.3, mean 2.7, $\mathrm{N}=5$ ). Dorsal and ventral regions of body of same color, spiracular line indistinct Xestia (Pachnobia) atrata (Morrison, 1874) Inner tooth of mandible triangular, distance between ocelli Oc1-Oc2 on head shorter than that of Oc2-Oc3 (ratio Oc1-Oc2/Oc2-Oc3 ranges 0.5-1.0, mean 0.8, $\mathrm{N}=$ 44), seta D2 more distant from spiracle on Ab2 (ratio SD1-SD2/SD2-spiracle ranges 1.1-2.5, mean 1.7, $\mathrm{N}=43$ ). Ventral region of body paler than dorsal region, spiracular line visible and bordered sharply against subdorsal zone. 13 Frontal stripe of head pale brown or pale greyish brown, paler than cervical stripe, bases of setae D1 and D2 of abdomen ventrally yellowish white, spiracular line with yellowish white dorsal part and mottled by reddish brown elements

Xestia (Pachnobia) speciosa (Hübner, 1813) Frontal stripe dark greyish brown like cervical stripe, bases of D1 and D2 of abdomen ventrally whitish, small spiracular line without differentiated white dorsal part and not mottled by brown elements Xestia (Pachnobia) viridescens (Turati, 1919) Larva green, mottled with small, white elements, without prominent pattern, dorsal, subdorsal and spiracular lines white, narrow. Setal distance D1-D2 of Ab9 about 1/2 distance D1-SD1 (ratio D1-D2/D1-SD1 range 0.5-0.7, mean 0.6, $\mathrm{N}=2$ )

Xestia (Pachnobia) brunneopicta (Matsumura, 1925) Larva not uniformly green, dark dorsal pattern present on body, lines variable. Setal distance D1-D2 of Ab9 about as long as distance D1-SD1 (ratio D1-D2/D1-SD1 range $0.7-1.3$, mean $1.0, \mathrm{~N}=42$ )

Spinneret long, more than $3 \times$ as long as wide and tapered apically; setal distance SD1SD2 less than twice as long as that of SD2-spiracle on Ab8 (except aequaeva 2.5-3.1 $\times$ ), range 1.4-3.1, mean 1.8, $\mathrm{N}=19$. Ground colour of larva distinctive dark grey with dorsal pinacula or dorsal zone pinkish cream and subdorsal zone blackish 16 Spinneret shorter, less than $3 \times$ as long as wide with parallel sides; setal distance SD1SD2 more than $2 \times$ as long as that of SD2-spiracle on Ab8 (except sincera 1.5-1.9 $\times$ ), range 1.5-4.5, mean 2.5, $\mathrm{N}=102$. Ground colour of larva different 17 Larva dark grey with large black pinacula on dorsal region, spiracles black, number of crochets on Ab10 varies 17-24 ( $=2)$, setal distance L1-L3 on metathorax about $3 \times$ that of L1-L2 (range 2.6-3.3, mean 2.9, $\mathrm{N}=2$ ).

Xestia (Pachnobia) aequaeva (Benjamin, 1934)

Pinacula absent on dorsal region, ground colour different, spiracles yellowish, number of crochets on Ab10 varies 26-43 $(\mathrm{N}=19)$ setal distance L1-L3 about $1.5 \times$ that of L1-L2 (range 1.2-2.0, mean 1.5, $\mathrm{N}=19$ ) on metathorax. Dorsal zone of larva pale pinkish cream, white, usually only ventrad from seta D2 visible subdorsal lines with 
blackish dorsal border, subdorsal zone blackish brown

Xestia (Pachnobia) gelida (Sparre-Schneider, 1883)

17 Tiny spinules present distally on middle of posterior part of hypopharynx and partly forming transverse rows, inner tooth of mandible small, seta SD1 on abdominal segments more distant from spiracle (on Ab8 ratio SD1-spiracle/height of spiracle ranges 1.9-3.5, mean 2.3, $\mathrm{N}=5$ ). Body blackish grey and whitish, lichen patterned, middorsal line white, enlarged on posterior parts of abdominal segments, subdorsal line whitish, enlarged towards seta D2, spiracular line broad, white with dark breaks below spiracles and dorsally bordered by black wavy margin

Xestia (Pachnobia) sincera (Herrich-Schäffer, 1851)

Spines absent on middle posterior part of hypopharynx, inner teeth of mandible robust, seta SD1 on abdominal segments closer to spiracle (on Ab8 ratio SD1-spiracle/height of spiracle ranges $0.9-1.7$, mean $1.3, \mathrm{~N}=26$ ). Body brown or yellowish-brown, not lichen patterned, lines vary but spiracular line not prominent and its dorsal margin straight 18

18 Seta Lp2 of labial palpus short, 2/5 of length of base segment, spinneret slightly shorter than $2 \times$ as long as wide, setal distance XD1-XD2 about $2 \times$ as long as XD2-SD2 on prothorax (ratio XD1-XD2/XD2-SD2 range 2.0-2.5, mean 2.1, $\mathrm{N}=10$ ), on Ab2 distance SV1-SV3 longer than SV1-SV2 (ratio SV1-SV3/SV1-SV2 range 1.0-1.9, mean $1.3, \mathrm{~N}=10$ ). Larva reddish brown, dorsal lines whitish, narrow, both bordered with blackish fleck at anterior parts of segments, spiracular line yellowish white, sharp edged, figures of dorsal zone obscure .............Xestia (Pachnobia) tecta (Hübner, 1808) Seta Lp2 of labial palpus long, about 2/3-1 $\times$ length of base segment, spinneret 2-2.5 $\times$ as long as wide, setal distance XD1-XD2 about $1.5 \times$ that of XD2-SD2 on protho$\operatorname{rax}$ (ratio XD1-XD2/XD2-SD2 range 1.2-1.9, mean 1.5, $\mathrm{N}=17$ ), on Ab2 distance SV1-SV3 shorter than SV1-SV2 (ratio SV1-SV3/SV1-SV2 range 0.5-1.1, mean $0.8, \mathrm{~N}=17$ ). Larva yellowish or grayish brown with broad dorsal lines of same colour, bordered with sharp, black, narrow margins, subdorsal line without ventral margin, markings of dorsal zone like thin arrow-head chevron figure on Ab1-8, spiracular line of same colour, dorsally bordered with sharp, blackish margin....

Xestia (Pachnobia) lorezi (Staudinger, 1891)

\section{Discussion}

The appearance of the larval stages of $X$. brunneopicta differs greatly from those of $X$. gelida and $X$. fabulosa (Ferguson, 1965). This is a surprise considering the adult of $X$. brunneopicta has been considered to be closely related to them (Lafontaine et al. 1998). The larva of $X$. fabulosa is similar to that of $X$. gelida and therefore we supposed that the larva of X. brunneopicta could resemble this species as well. Ahola and Silvonen (2011) described larvae close to $X$. gelida as possible $X$. brunneopicta from Kuusamo and Kuhmo in Finland. These three larvae differ from $X$. gelida in having a paler dorsal zone, shorter visible part of the middorsal line, the subdorsal line is broken into flecks, has a narrower black dorsal margin of subdorsal line, is not enlarged on $\mathrm{Ab} 7-8$ and has a wider white dorsal part of the spiracular line. Also, setal positions 
are slightly different, and SD1 is more distant from the spiracles. However, we now rather see these differences as variation in $X$. gelida.

Many Noctuidae have green larvae. For example, in Europe there are more than 140 species with such larvae. Larvae with green bodies and narrow white dorsal and subdorsal lines are not so common, but still about 40 species have such larvae. However, a quarter of them can occur in the same northern areas with X. brunneopicta. In Finland larvae of Orthosia gothica (Linnaeus, 1758) and $O$. incerta (Hufnagel, 1766) resemble those of $X$. brunneopicta. The brown head and position of the spiracles above the spiracular line on Ab7 separates X. brunneopicta readily from Orthosia species. Xestia includes also two European species with green larvae, namely $X$. ochreago (Hübner, 1790) and some variations of $X$. castanea (Esper, 1798). They have, however, short dorsal setae, and the head is green.

DNA barcodes of $X$. brunneopicta differ from those of X. gelida and X. fabulosa by a minimum of $6.47 \%$ and $6.73 \%$ genetic distance, respectively (Marko Mutanen, pers. comm.), also suggesting that $X$. brunneopicta is perhaps not a very close relative of these species. Based on the COI sequences from one Finnish and one Russian specimen of $X$. brunneop$i c t a$, the closest relatives of $X$. brunneopicta are X. lorezi $(4.44 \%)$, X. sincera $(4.60 \%)$ and X. ursae (McDunnough, 1940) (4.61\%), but many other Xestia species show less than 6\% divergence as well. Based on DNA barcodes, no other Xestia species is a very close relative of $X$. brunneopicta, and based on both larval morphology and DNA barcodes, its sister species remains unclear.

\section{Acknowledgements}

We thank the Ella and Georg Ehrnrooth Foundation for their support of the expedition, and the members of the expedition Pekka Alestalo (Finland), Andrei Biksaleyev (Russia), Oleg Korsun (Russia) and Jukka Tiittanen (Finland) for fieldwork in the Chara area. The authors are also grateful to Vladimir V. Dubatolov (Russia) for identification of the other moth material, to Marko Mutanen (Finland) for comments on DNA barcoding and to Pekka Puntila (Finland) for the photographs of the mature larva. Our thanks are also due to Kari Nupponen (Finland) for helping with the manuscript, Lauri Kaila (Finland) for valuable comments and suggestions and Don Lafontaine (Canada) for reviewing this paper and for his important comments which helped to improve and clarify the text.

\section{References}

Ahola M, Silvonen K (2011) Pohjoisen Euroopan yökkösten toukat. Larvae of Northern European Noctuidae. Osa 3, volume 3. Viestipaino Oy, Tampere, $600 \mathrm{pp}$.

Beck H (1960) Die Larvalsystematik der Eulen. Abhandlungen zur Larvalsystematik der Insekten 4. Berlin, 406 pp.

Beck H (1974) Zur Beschreibung der Zeichnung (Ornamentik) von Insektenlarven. Eine Anleitung am Beispiel von Noctuidenlarven. Atalanta 5: 121-143.

Beck H (1999-2000) Die Larven der Europäischen Noctuidae. Revision der Systematik der Noctuidae (Lepidoptera, Noctuidae) Vol I-IV. Herbipoliana 5. Marktleuchten, 859+447 pp.

Fibiger M, Hacker HH (2005) Systematic list of the Noctuoidea of Europe (Notodontidae, Nolidae, Arctiidae, Lymantriidae, Erebiidae, Micronoctuidae and Noctuidae). Esperiana 11: 93-205. 
Hinton HE (1946) On the homology and nomenclature of the setae of lepidopterous larvae, with some notes on the phylogeny of the Lepidoptera. Trans. R. ent. Soc. Lond. 97: 1-37.

Kononenko VS (2005) An annotated check list of the Noctuidae (s.1.) (Insecta, Lepidoptera) of the Asian part of Russia and the Ural region. Noctuidae Sibiricae, Vol. I. Entomological Press, Sorø, 243 pp.

Lafontaine JD (1998) Noctuoidea, Noctuidae (part - Noctuini). In: Dominick RB et al. The Moths of America North of Mexico, fasc.27.3: 1-348.

Lafontaine JD, Mikkola K, Kononenko VS, Ahola M (1998) Subgenus Pachnobia Guenée. In: Lafontaine JD. Noctuoidea, Noctuidae (part - Noctuini). In: Dominick RB et al. The Moths of America North of Mexico, fasc.27.3, 139-165.

Mikkola K, Sinervirta M, Vaalamo K (1989) Xestia brunneopicta (Matsumura) new to Europe (Lepidoptera, Noctuidae). Baptria 69: $33-37$.

Patočka J, Turčáni M (2005) Lepidoptera Pupae. Central European Species. Text volumes. Apollo Books, Steenstrup, $542 \mathrm{pp}$.

Poole RW (1989) Noctuidae. Lepidopterorum Catalogus (New Series), fasc. 118: 1-1314. 